\title{
Electron Beam Melting and Refining of Metals and Alloys
}

\author{
Alok CHOUDHURY and Eckart HENGSBERGER \\ Metallurgical Department, LEYBOLD DURFERRIT GmbH, Rueckinger Straße 12, D-6455 Erlensee, Germany.
}

(Received on December 10, 1991; accepted in final form on February 28, 1992)

\begin{abstract}
The increasing need for improved refractory and reactive high strength materials has led to the development of special production processes. This article will consider electron beam melting and refining which is playing an important role especially in the production of nickel base superalloys, specialty steels, refractory metals such as tantalum, niobium, tungsten, and molybdenum and reactive metals such as hafnium, vanadium, zirconium, and titanium and their alloys. The drip and cold hearth melting and refining techniques including the electron beam heat sources are described. Process data and results for various materials are given.
\end{abstract}

KEY WORDS: electron beam; EB-drip melting; EB-cold hearth remelting; EB-button melting; refractory and reactive metals; superalloy.

\section{Introduction}

Increasing requirements for refractory and reactive high strength materials suitable for use at high temperatures in an aggressive atmosphere, ultra-pure materials typically required for, e.g., sputter targets and new alloys, have led to the development of special production processes in order to ensure metal products of the most exact composition, required grain-structure and highest purity.

One of these production processes is electron beam (EB) melting and refining, introduced more than 30 years ago. EB melting and refining is playing an increasingly important role in the production of nickel-base superalloys, specialty steels, refractory metals like tantalum, niobium, very pure tungsten and molybdenum, especially for the electronic industry, and reactive metals like hafnium, vanadium, zirconium, and titanium including their alloys.

Purification of the material is done by the removal of volatile elements contained in the material or performed during the melting process under vacuum by distillation or degassing. In addition to these cleaning effects, positive conditions for the cast product structure (segregation, porosity, etc.) can be achieved, because electron beam melting is a surface heating method, producing only a shallow pool.

To fulfil the specific melting and refining requirements, several processes like drip melting, floating zone melting, cold hearth (continuous flow) melting and button melting have been developed, using very flexible electron beam heat sources. Some advantages and limitations of the competing processes like sintering and vacuum arc remelting are given in Table 1 . $^{1)}$

\section{Electron Beam Melting Characteristics}

Electron beam melting and refining technology is characterized by the following main features:

- Melting in a wide vacuum range $\left(10^{-4}-10 \mathrm{~Pa}\right)$ in

Table 1. Comparison of characteristics of electron beam melting and competing processes.

\begin{tabular}{|c|c|c|c|c|c|c|}
\hline \multirow[b]{2}{*}{ Metal } & \multicolumn{2}{|c|}{$\Gamma_{-}$Sintering } & \multicolumn{2}{|c|}{ Vacuum arc melting - } & \multicolumn{2}{|c|}{ Electron beam melting } \\
\hline & Advantages & Limitations & Advantages & Limitations & Advantages & Limitations \\
\hline $\begin{array}{l}\text { Tungsten. } \\
\text { molybdenum. }\end{array}$ & $\begin{array}{l}\text { Small grain size: } \\
\text { most often used }\end{array}$ & $\begin{array}{l}\text { Refining limited: } \\
\text { small batches: } \\
\text { high energy } \\
\text { consumption }\end{array}$ & $\begin{array}{l}\text { Mojerate grain size: } \\
\text { acceptable workability: } \\
\text { large ingots; low energy } \\
\text { consumption }\end{array}$ & $\begin{array}{l}\text { Refining limited: } \\
\text { costly electrode } \\
\text { preparation: melting } \\
\text { dangerous }\end{array}$ & $\begin{array}{l}\text { Highest possible purity; } \\
\text { economical feedstock } \\
\text { preparation: large } \\
\text { ingots: low energy } \\
\text { consumption }\end{array}$ & $\begin{array}{l}\text { Large grain size: } \\
\text { brittle product: } \\
\text { very rarely applied }\end{array}$ \\
\hline Tantalum, niobium... & $\begin{array}{l}\text { Small grain size: } \\
\text { good workability }\end{array}$ & $\begin{array}{l}\text { Same as above; } \\
\text { rarely applied }\end{array}$ & $\begin{array}{l}\text { Alloying: moderate grain } \\
\text { size: large ingots: low } \\
\text { energy consumption }\end{array}$ & $\begin{array}{l}\text { Refining limited: } \\
\text { expensive electrode; } \\
\text { melting dangerous }\end{array}$ & $\begin{array}{l}\text { Same as above: most } \\
\text { frequently used }\end{array}$ & Alloying limited \\
\hline Hafnium, vanadium. . & $\ldots \ldots \ldots$ & Same as above & Alloying during remelting & $\begin{array}{l}\text { Almost no refining: } \\
\text { costly electrode } \\
\text { preparation: melting } \\
\text { dangerous }\end{array}$ & $\begin{array}{l}\text { Good refining: } \\
\text { economical feedstock } \\
\text { preparation and ingot } \\
\text { production; most } \\
\text { often used }\end{array}$ & High melting costs \\
\hline Zirconium, titanium. . & $\cdots \cdots \cdots$ & Not used & $\begin{array}{l}\text { Very low contamination; } \\
\text { wide range of alloying } \\
\text { possible: large ingots: } \\
\text { low energy consumption; } \\
\text { economical melting }\end{array}$ & $\begin{array}{l}\text { Limited refining: } \\
\text { expensive feedstock } \\
\text { preparation: only } \\
\text { round ingots }\end{array}$ & $\begin{array}{l}\text { Economical feedstock } \\
\text { preparation: refining } \\
\text { of high-density } \\
\text { inclusions: melting of } \\
\text { slabs, ingots. and } \\
\text { rods; high production } \\
\text { rate; low energy } \\
\text { consumption }\end{array}$ & $\begin{array}{l}\text { Alloying limited; } \\
\text { material losses } \\
\text { from splatter: high } \\
\text { furnace investment }\end{array}$ \\
\hline
\end{tabular}




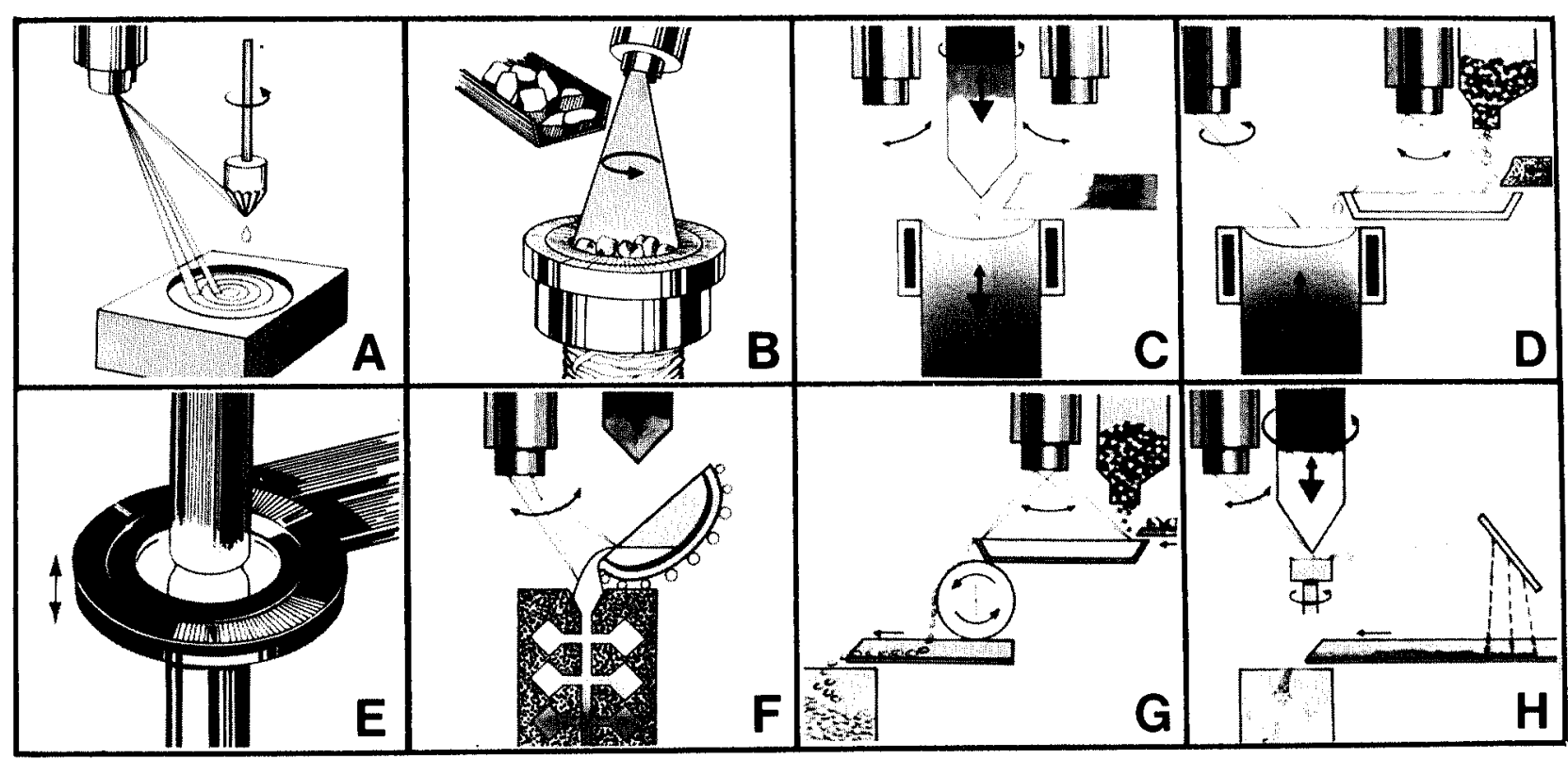

Fig. 1. Principles of electron beam melting.

(A) Bottom melting for determination of nonmetallic inclusions, (B) Consolidation of raw material to remelting electrodes, (C) Dripmelt of horizontally and vertically fed feedstock material, (D) Continuous flow or cold hearth refining melting, (E) Floating zone melting, (F) Investment casting, (G) Manufacturing of pellets from scrap for investment casting, $(\mathrm{H})$ Atomizing/granulating of refractory/reactive metals.

a ceramic-free, water-cooled copper trough (cold hearth melting) or crucible free to avoid any contamination

- High flexibility of melting rate and conditions for removal of volatile trace elements

- Nearly unlimited melting temperature

- High power density $\left(10^{3}-10^{6} \mathrm{~W} / \mathrm{cm}^{2}\right)$ available for local superheating

- Favorable conditions, especially in a cold hearth, to remove low density as well as high density inclusions

- Good control of ingot solidification for desired primary structure

- Production of highest quality ingots of various size, shape and quantity

- High flexibility in size, shape and quality of the feedstock material

- Automation of the process.

Figure 1 shows examples of the application of the electron beam melting methods. In all these processes, high performance EB guns of the Pierce-type are the key components. These EB guns are characterized by the following main features:

- Broad power range of 0 to $1200 \mathrm{~kW}$

- Optimum beam flexibility; deflection angle $\pm 45^{\circ}$, spot frequency up to $1000 \mathrm{~Hz}$

- Long free beam path of 250 to $1500 \mathrm{~mm}$.

Separate pumping of the beam generation system and the pre-focussing chamber allows melting in the pressure range of $10^{-4}$ to $10 \mathrm{~Pa}$ in the melt chamber. ${ }^{2)}$

Figure 2 shows a cross section of such a modern high power EB gun. In combination with adequate high voltage power supplies with thyristor-controlled rectifier units (SCR) guaranteeing low output tripple voltages for sharp beam focussing and a versatile EB-control system (Fig. 3) very accurate beam power and energy distribution can be achieved, thus allowing the required heating for meterial melting, superheating, refining and electrothermal effects.

\section{Melting Technique-State of the Art}

The electron beam melting process is applied worldwide to melt and cast ductile refractory metal ingots of niobium, tantalum, and hafnium. Superclean tungsten and molybdenum for the electronic industry as well as vanadium of high purity are also produced using EB furnaces. Nickel-base superalloys are refined and titanium scrap is recycled to produce not only ingots but also slabs. Research facilities are melting various kinds of conventional and exotic metals and alloys, e.g. rare earth alloys, intermetallic materials, ceramic, uranium, and copper to develop new grades or to purify said materials.

For these applications mainly drip melting and cold hearth (continuous flow) melting processes are primarily used. Button melting serves for cleanliness evaluation especially of superalloys. Investment skull casting with an electron beam heat source has been used for the production of titanium and superalloy turbine parts.

\subsection{Drip Melting}

Developed as a melting and refining process for the production of ductile tantalum and niobium ingots, this technique is nowadays mainly applied to the refining of refractory and reactive metals, e.g. tungsten, tantalum, niobium, hafnium, vanadium, etc.

To obtain optimum ingot quality in regard to cleanliness, structure, and surface, the material is remelted several times, starting with raw material, which is normally horizontally fed above the water-cooled copper 
crucible in the form of bars. These bars are mostly compacted, presintered, alumino-thermically reduced or preconsolidated. The continuous cast ingot is of sufficient purity, however, as a result of the shadow effect of the horizontally fed bar, a zone of lower quality is produced,

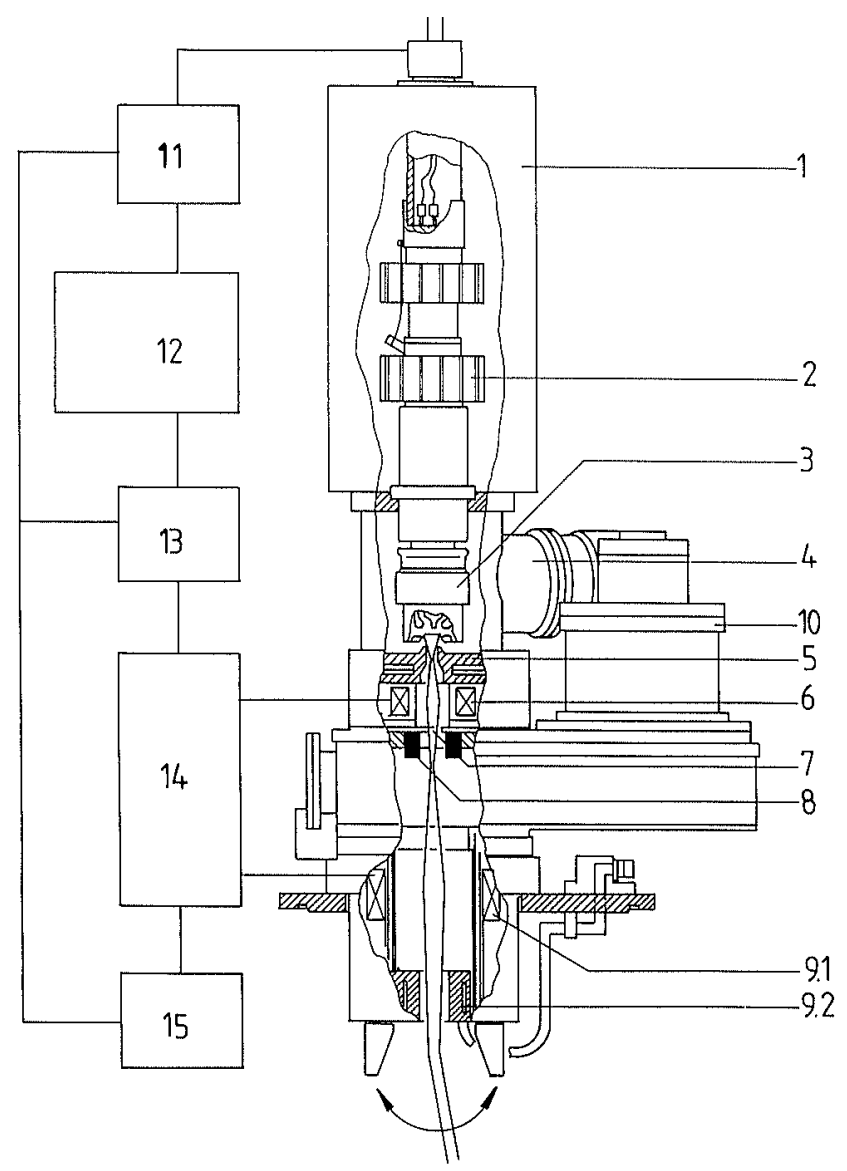

Fig. 2. Cross section of a modern high power EB gun (type KSR, manufactured at Leybold).

(1) High voltage protection hood, (2) High voltage isolator with plug and cooling vanes, (3) Cathode heating system, (4) Gun chamber, (5) Accelerating anode, water-cooled, (6) Upper magnetic lens, (7) Gun shutter valve, (8) Ion mirror, (9) Beam guiding system, (9.1) Lower magnetic lens, (9.2) Defiection and scanning system, (10) Vaccum pump, (11) Cathode heating power supply unit, (12) Main high voltage power supply unit, (13) EB power control, (14) EB focussing and distribution power supply, (15) Microprocessor-controlled EB power and distribution control unit. making a second remelting necessary.

For the second and third melt, the ingot feedstock is fed vertically (Fig. 4). The slow rotation of the feedstock (electrode) and the use of two or more EB guns eliminate the shadow effect. The molten metal runs down the conical electrode tip, is refined and drops into the centre of the molten pool in the crucible, where it is finally refined, homogenized, solidified, and continuously withdrawn. The power distribution of the electron beam between electrode and pool allows control of the pool depth and bath movement.

Table 2 shows typical process data for refractory metals remelted in drip melting furnaces. Reactive metals, e.g. zirconium and titanium are predominantly refined in vacuum arc remelting furnaces to remove the dissolved hydrogen. However, if the carbon content of zirconium also has to be reduced, ${ }^{3)}$ cold hearth melting is more suitable. Remelting of specialty steels is limited to alloys with a manganese content of less than $0.1 \%$. However, the product has an extremely reduced content of undesired metallic and nonmetallic impurities. ${ }^{4,5)}$

\subsection{Drip Melting Furnaces}

Figure 5 shows a typical $500 \mathrm{~kW}$ electron beam drip melting furnace, mainly used for the production of tantalum and niobium ingots. The furnace is equipped with two EB guns, a horizontal and a vertical feeding system, a crucible for continuous casting and a withdrawal system. The vacuum pump set maintains an operating pressure below $10^{-3} \mathrm{~Pa}$. View ports allow visualization of the process via video systems. All operating parameters such as electron beam power and deflection, operating pressure, material feed rate and withdrawal speed are adjusted, controlled, and recorded

\subsection{Cold Hearth Melting}

EB cold hearth melting was first applied about 25 years ago for the refining of steel. ${ }^{6}$ ) Today, cold hearth melting is mainly used for the recycling and refining of reactive metal scrap and the refining of superalloys (Fig. 6) and specialty steels.

Melting in a water-cooled copper hearth has the advantage over EB-dripmelting, vacuum arc remelting (VAR) and electroslag remelting (ESR) of separating melting, refining and solidification, making individual control of every single step of the process possible.

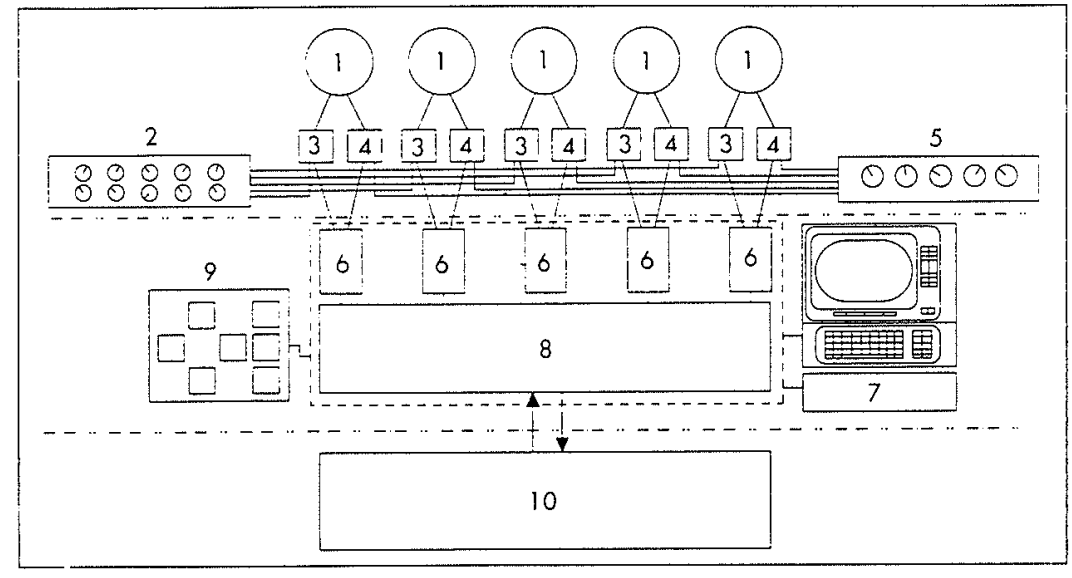

Fig. 3.

Computer control system for up to 5 electron beam guns.

(1) EB gun, (2) Manual override, static deflection, (3) Drives for focus and deflection, (4) Emission constanter, (5) Manual override beam power 0-120\%, (6) Intelligent analogue interface board, (7) Keyboard, screen, hard- and floppy-disc drive, (8) Microprocessor, (9) Remote control, (10) Programmable logic controller (PLC). 


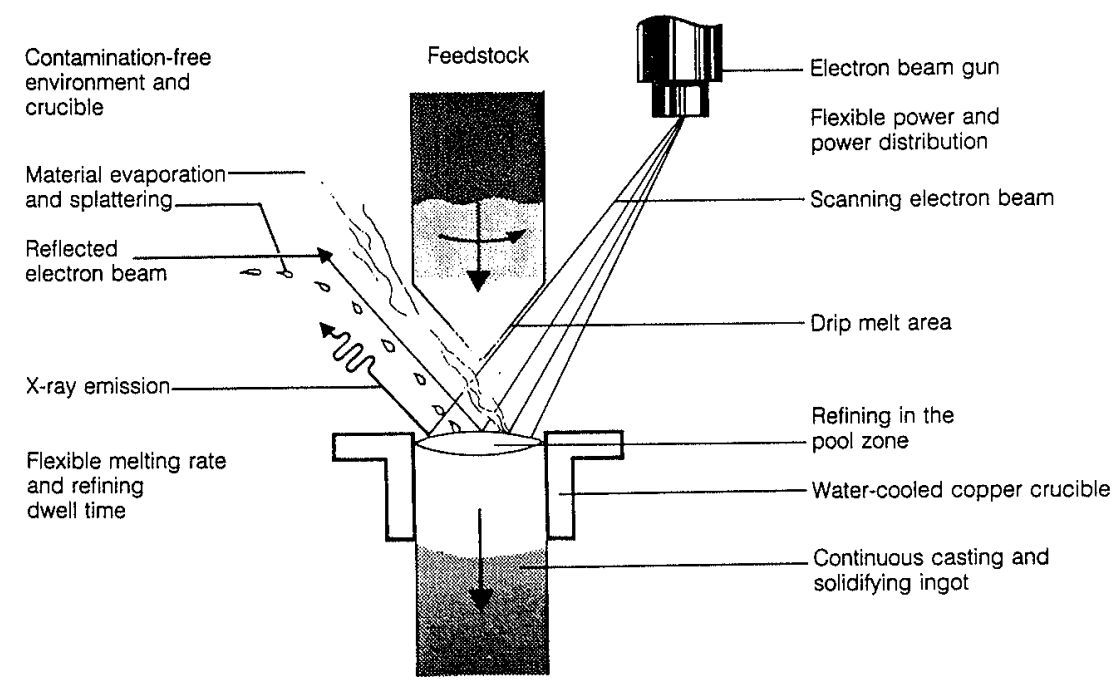

Fig. 4.

Electron beam melting process (schematic).

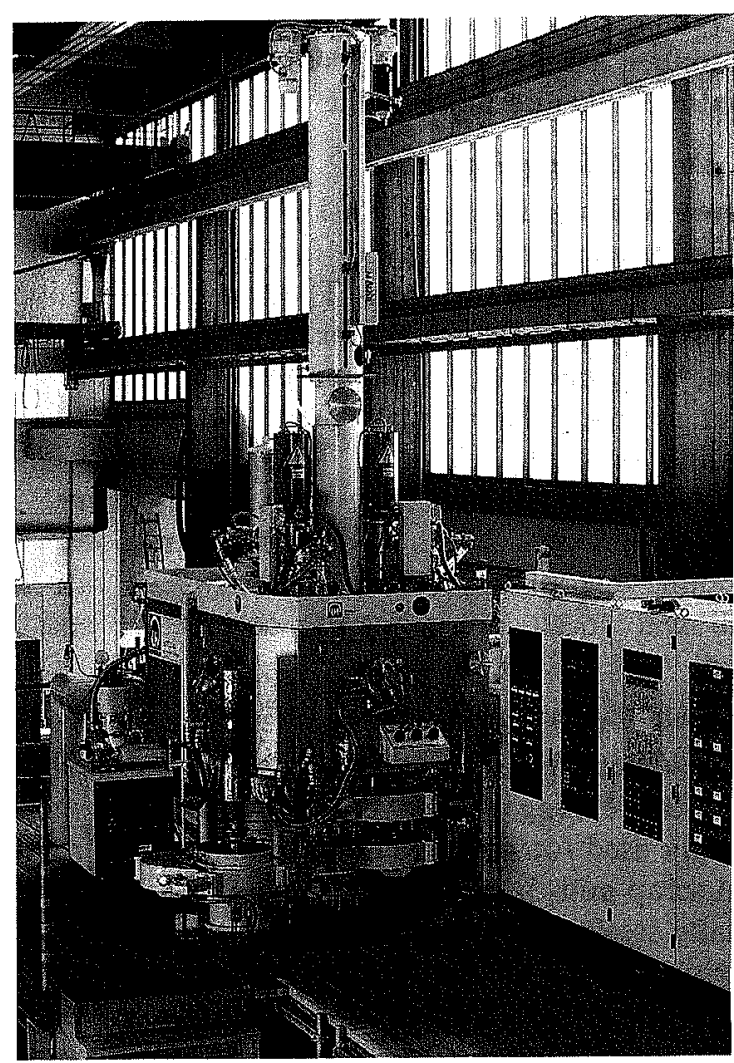

Fig. 5. $500 \mathrm{~kW}$ electron beam drip melting furnace.

The hearth design can be adapted to the feeding of different feedstocks (Fig. 7). Beside bars and compacts, sponge, scrap and chips can be fed and melted at the rear end of the hearth. Refining of the material in the hearth is based on the following processes ${ }^{7,8)}$ :

- Vacuum distillation of highly volatile elements and compounds, e.g. $\mathrm{H}, \mathrm{CO}, \mathrm{Cl}, \mathrm{N}$ suboxides.

- Sedimentation of inclusions having a higher density than the melt (HDIs), e.g. tungsten carbide particles from titanium scrap. The density of these particles should be more than double than that of the melt, and the size larger than $1.5 \mathrm{~mm}$ to achieve a reliable separation process. The particles sink down in the boundary layer between liquid and dense material and

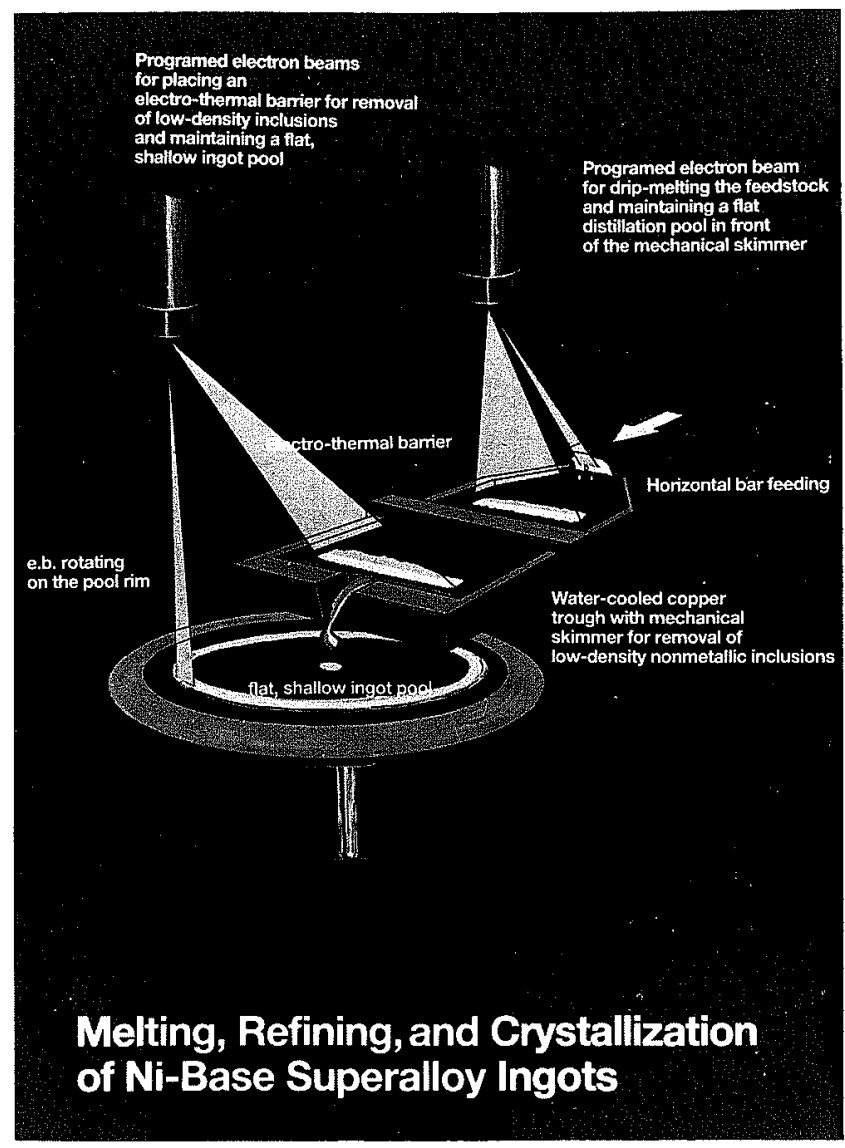

Fig. 6. Cold hearth (trough) melting of superalloys (schematic).

are trapped in this mushy zone.

- Flotation of inclusions with lower density (minimum $40 \%$ ) in respect to the melt, e.g. aluminum or magnesium oxides from steel or nickel-base alloys. These low density inclusions (LDIs) with a size larger than approximately $25 \mu \mathrm{m}$ float to the surface of the melt and are retained by means of a mechanical skimmer or electrothermal barrier. The latter is an EB generated small superheated zone covering the entire width of the heart.

- Adhesion of inclusions with a density comparable to 
Table 2. Typical process data of some dripmelting furnaces.

\begin{tabular}{|c|c|c|c|c|c|c|c|c|c|c|c|c|c|}
\hline $\begin{array}{l}\text { rurnace } \\
\text { type }\end{array}$ & Material & $\begin{array}{c}\text { Ingot } \\
\text { diameter, } \\
\text { mm }\end{array}$ & $\begin{array}{c}\text { Ingot } \\
\text { weight, } \\
\text { kg }\end{array}$ & $\begin{array}{l}\text { Melt } \\
\text { rate, } \\
\mathrm{kg} / \mathrm{h}\end{array}$ & $\begin{array}{c}\text { EB } \\
\text { power. } \\
\text { kW }\end{array}$ & $\begin{array}{l}\text { Operating } \\
\text { vacuum, } \\
\text { mbar }\end{array}$ & $\begin{array}{c}\text { Melt } \\
\text { energy, } \\
\mathrm{kWh} / \mathrm{kg}\end{array}$ & $\begin{array}{c}\text { Material } \\
\text { yield, } \\
\%\end{array}$ & $\mathrm{C}^{\mathrm{Ar}}$ & nalysis & $i_{\mathrm{N}, \mathrm{ppo}}$ & $m_{H}$ & $\begin{array}{c}\text { Brinell } \\
\text { hardness, } \\
\mathrm{kg} / \mathrm{mm}^{2}\end{array}$ \\
\hline \multirow[t]{3}{*}{ ES $2 / 12 / 100$} & .. Tungsten & & & & & & & & 704 & 100 & 30 & 10 & \\
\hline & 1. Melt & 40 & 19 & 20 & 98 & $5 \times 10^{-5}$ & 4.9 & 95.5 & 45 & 115 & 11 & 1 & \\
\hline & 2. Melt & 60 & 37 & 22 & 119 & $8 \times 10^{-6}$ & 5.4 & 97.5 & 10 & 8 & 5 & 1 & 200 \\
\hline \multirow[t]{9}{*}{ ES $2 / 50 / 400$} & . Niobium & & & & & & & & 804 & 500 & 330 & 40 & \\
\hline & 1. Melt & 140 & 210 & 25 & 218 & $5 \times 10^{-5}$ & 8.7 & 98.7 & 22 & 190 & 90 & 13 & \\
\hline & 2. Melt & 140 & 206 & 28 & 201 & $8 \times 10^{-6}$ & 7.2 & 98.1 & 6 & 111 & 52 & 8 & 66 \\
\hline & Molybdenum & & & & & & & & 200 & 750 & 60 & 10 & \\
\hline & 1. Melt & 180 & 415 & 84 & 245 & $5 \times 10^{-5}$ & 2.9 & 98.3 & 40 & 90 & 10 & 4 & \\
\hline & 2. Melt & 180 & 408 & 125 & 290 & $8 \times 10^{-6}$ & 2.3 & 98.5 & 10 & 12 & 11 & 2 & 140 \\
\hline & Tantalum & & & & & & & & 32 & 650 & 25 & 10 & \\
\hline & 1. Melt & 160 & 534 & 74 & 276 & $5 \times 10^{-5}$ & 3.7 & 93.2 & 8 & 45 & 17 & 5 & \\
\hline & 2. Melt & 160 & 523 & 80 & 371 & $8 \times 10^{-6}$ & 4.6 & 98.5 & 6 & - 15 & 13 & 2 & 69 \\
\hline
\end{tabular}
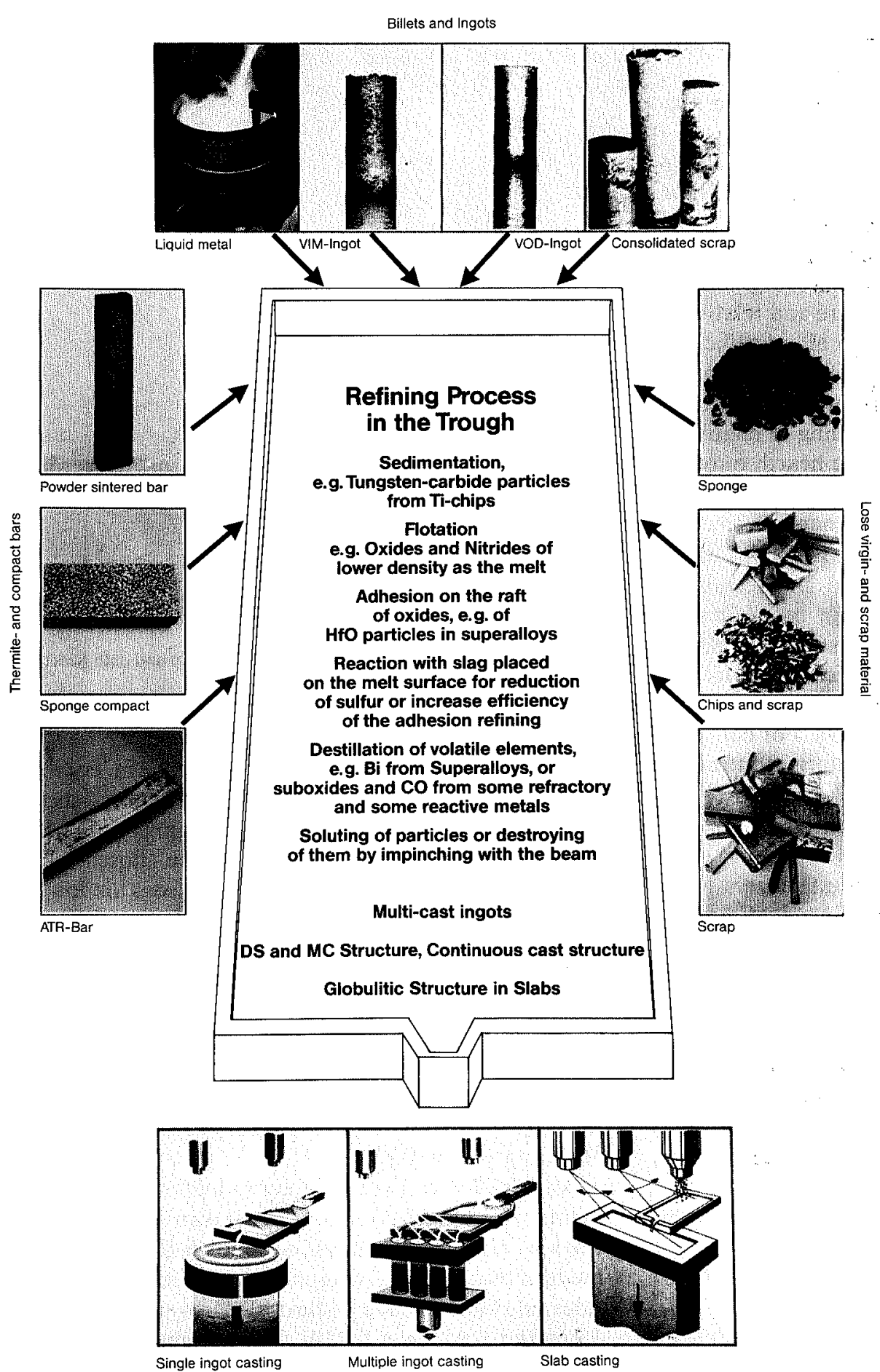

Fig. 7.

Feedstock for cold hearth melting and refining process using an EB heat source. 


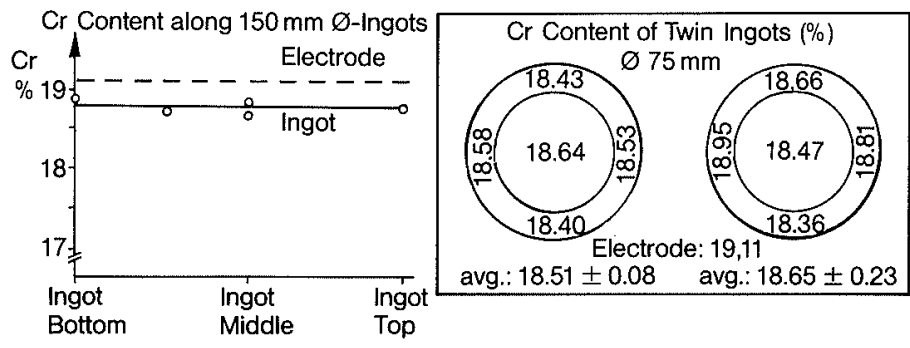

Fig. 8.

Chromium distribution in twin ingots.

the melt. Due to movement of the bath, such particles float to the surface of the melt and are trapped by adhesion in a slag raft of other floating inclusions.

- Dissolution or dissociation (also LDIs) by superheating the bath or a bath zone, material is passing through. Relatively high surface temperatures also create favorable conditions for the evaporation of undesired trace elements such as $\mathrm{Pb}, \mathrm{Se}, \mathrm{Zn}, \mathrm{Ca}$ etc.

- Reaction refining using a reactive gas passing over the molten material.

The degree of purification is dependent on the melting rate and the hearth geometry. At low melting rates, good purification is obtained. However, there is an increase in the loss of elements having high vapour pressure such as chromium and aluminum during EB melting.

Reference 1) recommends nearly square and relatively deep hearths for vacuum distillation to allow sufficient melt stirring. For flotation refining of, for example, superalloys a long and narrow hearth is recommended, whereas for titanium alloy scrap recycling a relatively short trough can be used. Linked to the hearth only by the liquid metal flow, the casting and solidification process can be very flexibly controlled, thereby ensuring a homogeneous ingot grain structure. The final ingot may take various shapes; besides round and rectangular ingots, slabs and hollow ingots ${ }^{9)}$ can be produced. Furthermore, the casting of multiple barsticks with small diameters is used in the production of feed material for VIM- or EB-precision casting furnaces, e.g. when forging of the material is critical due to brittleness. For complex geometrics a sophisticated beam pattern control is required.

\subsection{Cold Hearth Refining for Cleaner Metals}

Major American aircraft engine manufacturers have issued a material specification, including cold hearth melting for the production of premium quality titanium alloys for aircraft components. It is a proven fact that non-metallic inclusions have led to failure in aircraft engines. Therefore, a great deal of effort has been spent to obtain defect-free material ${ }^{10)}$ and cold hearth melting has proven to be the most favourable process fulfilling the demands for freedom, not only from tungsten carbide tool tips (HDIs) but also from titanium nitrides ${ }^{11)}$ and other interstitial high impurities (IHIs). These are demands, conventional process routines such as vacuum arc remelting intrinsically cannot fulfil.

The reduction of nonmetallic inclusions in nickel-base superalloys, especially the complete elimination of inclusions larger than $10 \mu \mathrm{m}$, significantly improves these mechanical properties. ${ }^{12)} \mathrm{EB}$ cold hearth refining is the

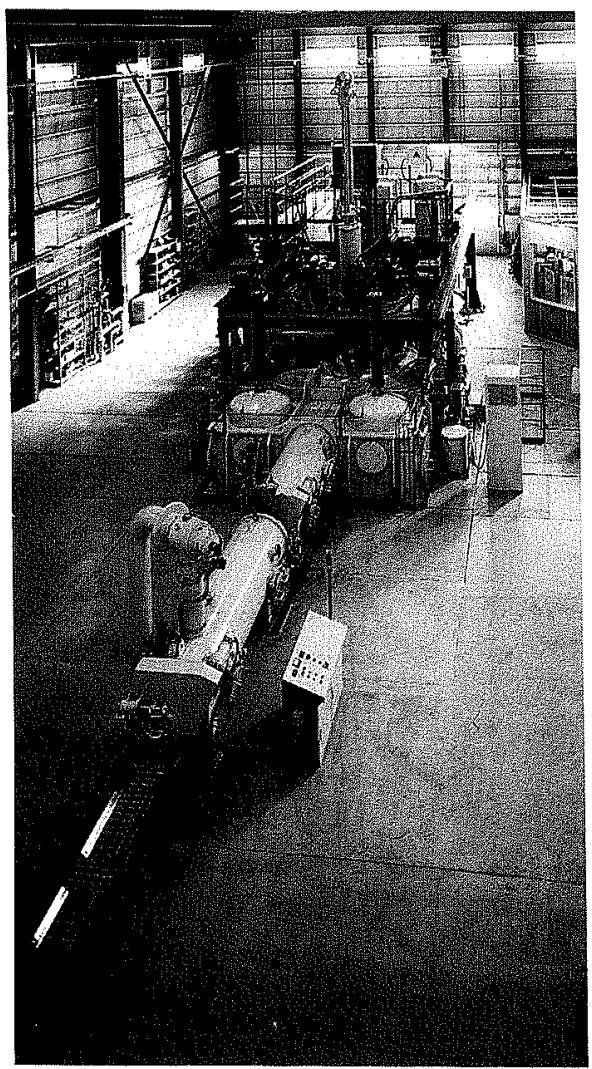

Fig. 9. Four gun $2400 \mathrm{~kW}$ electron beam drip and cold hearth melting furnace.

ideal process to fulfil these requirements in combination with a minimum loss of volatile elements such as chromium and aluminium, when the appropriate hearth length for the desired melt rate has been chosen. Under these operating conditions, chromium losses are low and nearly constant in the cross section and over the length of the ingot (Fig. 8).

Further melt tests ${ }^{13)}$ of IN 718 showed that with cold hearth refining the content of LDIs larger than $25.5 \mu \mathrm{m}$ could be reduced from 426 to 19 per pound; also multi-strand cast IN 718 barsticks showed no major segregation. Typical process parameters and data for the cold hearth melting of refractory and reactive metals etc. are given in Table 3. ${ }^{1}$ )

An EBCHR furnace for the production of superalloy ingots with weights up to $13 \mathrm{t}$ is shown in Fig. 9. Four $600 \mathrm{~kW}$ electron beam guns controlled by the most modern computerized equipment are used to realize melt rates of $1000 \mathrm{~kg} / \mathrm{h}$ and to heat a hearth with a length of $1.2 \mathrm{~m}$ and a width of $0.35 \mathrm{~m}$. The automated horizontal feeding of typically VIM-cast electrodes, normally almost 
ISIJ International, Vol. 32 (1992), No. 5

Table 3. Refining and production data for the continuous flow melting of reactive and refractory metals and stainless steels in laboratory and pilot production furnaces

\begin{tabular}{|c|c|c|c|c|c|c|c|c|c|c|c|c|c|c|c|}
\hline & & & & & & $\begin{array}{c}\text { Electron } \\
\text { berm }\end{array}$ & & $\begin{array}{l}\text { Speciflc } \\
\text { meiting }\end{array}$ & & Compos & tition of & feedst & ock and & product & \\
\hline Metal & $\begin{array}{l}\text { Feedstock size, } \\
\text { mm (in.) }\end{array}$ & $\begin{array}{l}\text { Trough size, } \\
\text { mm (in.) }\end{array}$ & $\begin{array}{l}\text { Ingot size. } \\
\mathrm{mm} \text { (in.) }\end{array}$ & $\begin{array}{l}\text { Ingot weight, } \\
\text { kg (lb) }\end{array}$ & $\begin{array}{l}\text { Melt rate. } \\
\mathrm{kg} / \mathrm{h}(\mathrm{lb} / \mathrm{h})\end{array}$ & $\begin{array}{c}\text { power, } \\
k W\end{array}$ & $\begin{array}{l}\text { pressure, } \\
\text { Pa (torr) }\end{array}$ & $\begin{array}{l}\text { energy, } \\
k W \cdot h / k_{B}\end{array}$ & $\begin{array}{c}\text { C, } \\
\text { ppm }\end{array}$ & $\begin{array}{c}0, \\
\text { ppm }\end{array}$ & $\begin{array}{l}\mathrm{N}, \\
\text { ppm }\end{array}$ & $\underset{\mathrm{ppm}}{\mathrm{H},}$ & $\begin{array}{l}\text { Al, } \\
\%\end{array}$ & vi & $\underset{\%}{C_{r}}$ \\
\hline Hafnium.......... & $60(2.4)$ square & $\begin{array}{l}120 \times 250 \\
(5 \times 10)\end{array}$ & 100 (4) diam & $83.0(183)$ & $40(88)$ & 180 & $\begin{array}{c}4 \times 10^{-2} \\
\left(3 \times 10^{-4}\right)\end{array}$ & 4.5 & $\cdots$ & $\begin{array}{l}900 \\
600\end{array}$ & $\cdots$ & $\cdots$ & $\cdots$ & $\cdots$ & $\cdots$ \\
\hline Zirconium........ & $100(4)$ square & $\begin{array}{l}120 \times 300 \\
(5 \times 12)\end{array}$ & $150(6)$ & $90.5(200)$ & $42(92.5)$ & 185 & $\begin{array}{c}3.5 \times 10^{-2} \\
\left(2.6 \times 10^{-4}\right)\end{array}$ & 4.4 & $\cdots$ & $\begin{array}{l}950 \\
540\end{array}$ & $\begin{array}{l}95 \\
30\end{array}$ & $\begin{array}{r}30 \\
3\end{array}$ & $\begin{array}{l}\cdots \\
\cdots\end{array}$ & $\begin{array}{l}\cdots \\
\cdots\end{array}$ & $\cdots$ \\
\hline Zirconium........ & $80(3.2)$ square & $\begin{array}{l}120 \times 300 \\
(5 \times 12)\end{array}$ & $100(4)$ & $40.2(89)$ & $80(176)$ & 140 & $\begin{array}{c}3.5 \times 10^{-2} \\
\left(2.6 \times 10^{-4}\right)\end{array}$ & 1.75 & $\begin{array}{l}\cdots \\
\cdots\end{array}$ & $\begin{array}{l}4000 \\
1520\end{array}$ & $\begin{array}{l}800 \\
210\end{array}$ & $\begin{array}{r}10 \\
3\end{array}$ & $\cdots$ & $\begin{array}{l}\cdots \\
\cdots\end{array}$ & $\cdots$ \\
\hline Vanadium....... & $50(2)$ square & $\begin{array}{l}120 \times 300 \\
(5 \times 12)\end{array}$ & $100(4)$ & $\cdots$ & $20(44)$ & 130 & $\begin{array}{c}1.5 \times 10^{-2} \\
\left(1.1 \times 10^{-4}\right)\end{array}$ & 6.5 & $\cdots$ & $\begin{array}{r}1045 \\
277\end{array}$ & $\begin{array}{r}210 \\
50\end{array}$ & $\begin{array}{r}10 \\
3\end{array}$ & $\cdots$ & $\begin{array}{l}99 \\
99\end{array}$ & $\cdots$ \\
\hline Ti-6Al-4V ........ & Swarf & $\begin{array}{l}120 \times 300 \\
15 \times 12)\end{array}$ & $150(6)$ & $62.6(138)$ & $40(88)$ & 122 & $\begin{array}{c}2 \times 10^{-2} \\
\left(1.5 \times 10^{-4}\right)\end{array}$ & 3.0 & $\begin{array}{l}400 \\
200\end{array}$ & $\begin{array}{l}2600 \\
2700\end{array}$ & $\begin{array}{l}110 \\
110\end{array}$ & $\begin{array}{l}84 \\
22\end{array}$ & $\begin{array}{l}6.0 \\
4.4\end{array}$ & $\begin{array}{l}4.0 \\
4.2\end{array}$ & $\cdots$ \\
\hline Ti-6A]-4V $\ldots \ldots \ldots$ & Solid scrap & $\begin{array}{l}120 \times 300 \\
(5 \times 12)\end{array}$ & $150(6)$ & $62.6(138)$ & $70(154)$ & 140 & $\begin{array}{c}7 \times 10^{-2} \\
\left(5.3 \times 10^{-4}\right)\end{array}$ & 2.0 & $\begin{array}{l}1520 \\
\ldots\end{array}$ & $\begin{array}{l}1520 \\
1320\end{array}$ & $\begin{array}{l}75 \\
76\end{array}$ & $\begin{array}{r}15 \\
8\end{array}$ & $\begin{array}{l}6.0 \\
4.8\end{array}$ & $\begin{array}{l}4.0 \\
4.1\end{array}$ & $\cdots$ \\
\hline $\begin{array}{l}\text { Ti-6A }-4 \mathrm{~V} \ldots \ldots \ldots \\
\text { Commercially pure }\end{array}$ & 125 (5) diam & $\begin{array}{l}150 \times 400 \\
(6 \times 16)\end{array}$ & $\begin{array}{c}2 \times 75(3) \\
\operatorname{diam}\end{array}$ & $2 \times 32(70.5)$ & $91(200)$ & 147 & $\begin{array}{c}6 \times 10^{-2} \\
\left(4.5 \times 10^{-4}\right)\end{array}$ & 1.61 & $\cdots$ & $\cdots$ & $\cdots$ & $\cdots$ & $\begin{array}{l}6.0 \\
3.6\end{array}$ & $\begin{array}{l}4.0 \\
4.3\end{array}$ & $\cdots$ \\
\hline $\begin{array}{l}\text { titanium........ } \\
\text { Commercially pure }\end{array}$ & $160(6.3)$ & $\begin{array}{c}150 \times 250 \\
(6 \times 10)\end{array}$ & $\begin{array}{c}100 \times 400 \\
(4 \times 16)\end{array}$ & $96.4(213)$ & $86.3(190)$ & 148 & $\begin{array}{c}6 \times 10^{-2} \\
\left(4.5 \times 10^{-4}\right)\end{array}$ & 1.71 & $\cdots$ & $\cdots$ & $\cdots$ & $\cdots$ & $\cdots$ & $\cdots$ & $\cdots$ \\
\hline titanium. . . . . & Sponge & $\begin{array}{l}150 \times 500 \\
(6 \times 20)\end{array}$ & $\begin{array}{c}100 \times 400 \\
(4 \times 16)\end{array}$ & $103.0(227)$ & $41.2(91)$ & 226 & $\begin{array}{c}8 \times 10^{-2} \\
\left(6 \times 10^{-4}\right)\end{array}$ & 5.5 & $\cdots$ & $\cdots$ & $\cdots$ & $\ldots$ & $\ldots$ & $\ldots$ & $\ldots$ \\
\hline Stainless steel .... & $150(6)$ diam & $\begin{array}{l}150 \times 400 \\
(6 \times 16)\end{array}$ & $2 \times 75(3)$ & $2 \times 55(121)$ & $136(300)$ & 144 & $\begin{array}{c}6 \times 10^{-2} \\
\left(4.5 \times 10^{-1}\right)\end{array}$ & 1.06 & $\begin{array}{l}701 \\
\$ 36\end{array}$ & $\begin{array}{l}97 \\
33\end{array}$ & $\begin{array}{r}155 \\
68\end{array}$ & $\cdots$ & $\cdots$ & $\cdots$ & $\begin{array}{l}18.25 \\
18.11\end{array}$ \\
\hline $\begin{array}{l}\text { Alloy } 718 \ldots \ldots \\
\text { AISl type } 316\end{array}$ & $133(5.2)$ diam & $\begin{array}{c}150 \times 400 \\
(6 \times 16)\end{array}$ & $\begin{array}{c}2 \times 75(3) \\
\text { diam }\end{array}$ & $2 \times 57(126)$ & $136(300)$ & 156 & $\begin{array}{c}6 \times 10^{-2} \\
\left(4.5 \times 10^{-4}\right)\end{array}$ & 1.15 & $\begin{array}{l}417 \\
363\end{array}$ & $\begin{array}{l}14 \\
17\end{array}$ & $\begin{array}{l}52 \\
34\end{array}$ & $\cdots$ & $\ddot{0} \ddot{72}$ & $\cdots$ & $\begin{array}{l}19.11 \\
18.73\end{array}$ \\
\hline stainless steel... & $150(6)$ diam & $\begin{array}{c}150 \times 400 \\
(6 \times 16)\end{array}$ & $\begin{array}{c}3 \times 65(2.6) \\
\text { diam }\end{array}$ & $\begin{array}{c}3 \times 41.5 \\
(91.5)\end{array}$ & $136(300)$ & 156 & $\begin{array}{c}6 \times 10^{-2} \\
\left(4.5 \times 10^{-4}\right)\end{array}$ & 1.15 & $\cdots$ & $\cdots$ & $\cdots$ & $\cdots$ & $\cdots$ & $\cdots$ & $\ldots$ \\
\hline
\end{tabular}

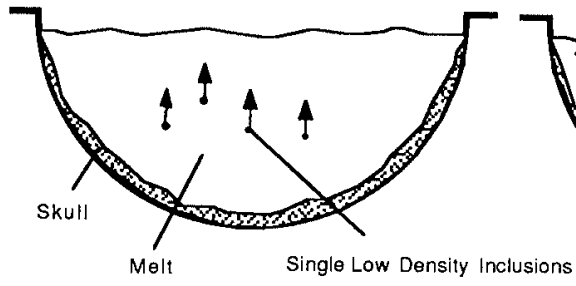

electrode

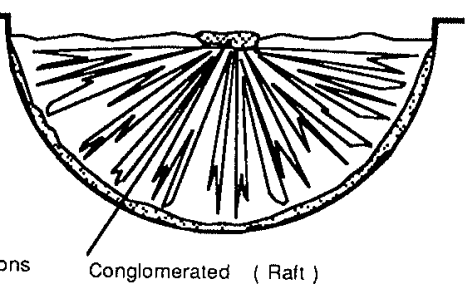

4II

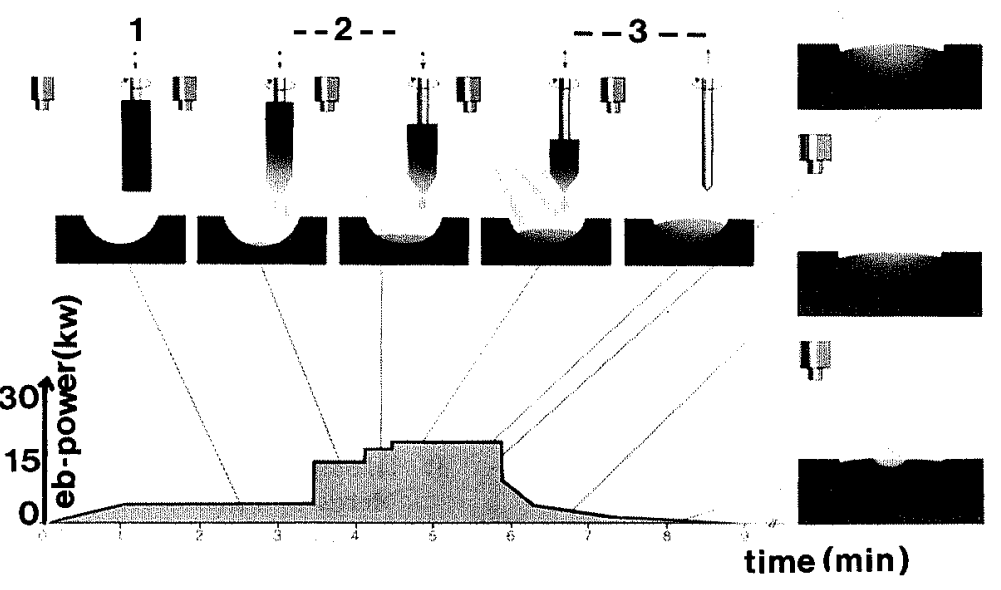

1 preheating 2 tip shaping 3 drip melting

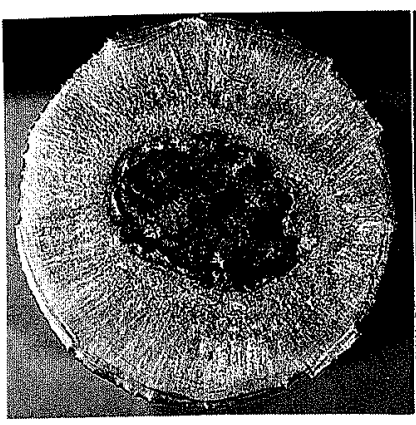

VIM-cast 738

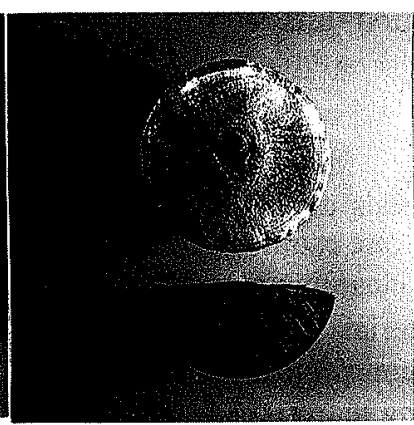

VIM-ESR-me1ted

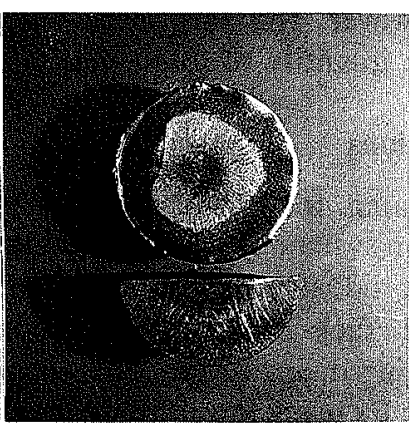

VIM-EBCF-cleaned

Fig. 10. Button melting process and button samples of superalloys. 


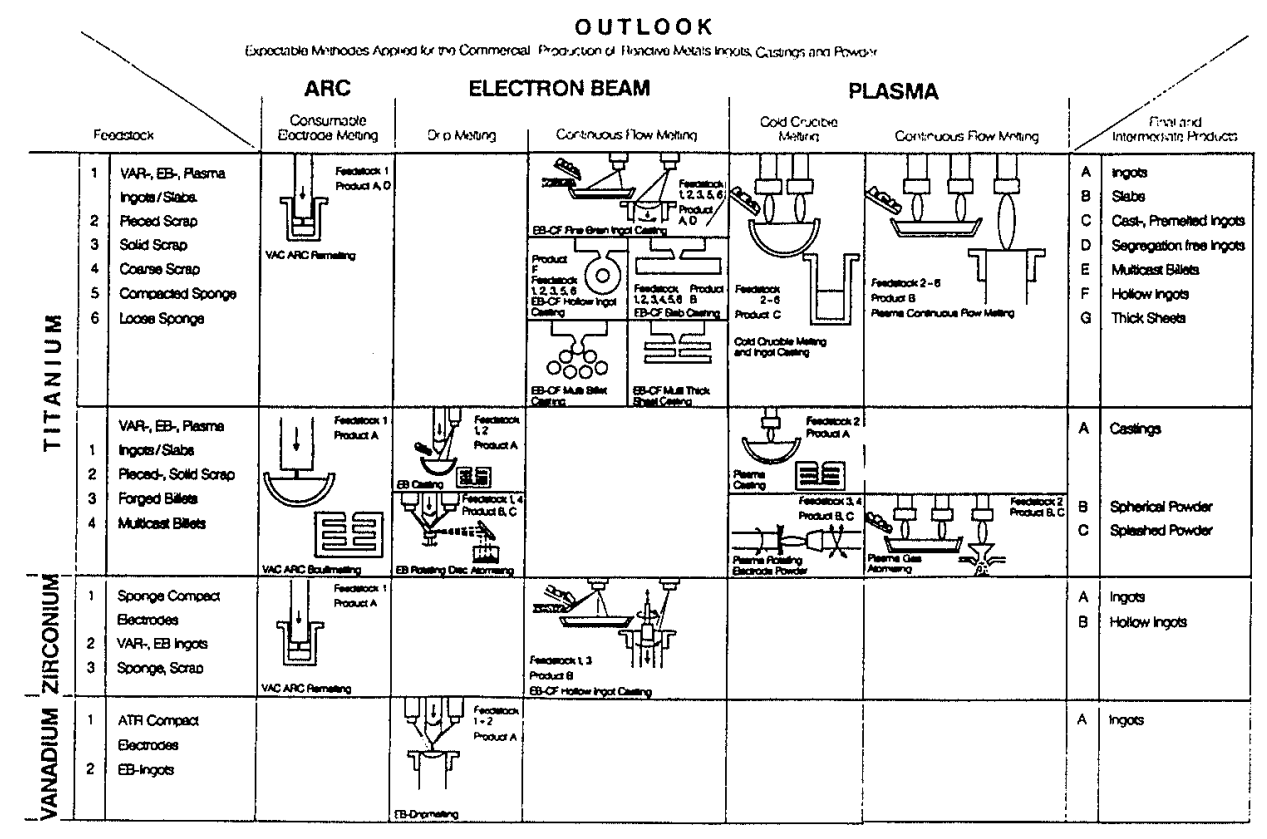

Fig. 11. Outlook on methods for production of reactive metals.

free of non-metallic inclusions and trace elements, ${ }^{14)}$ allows continuous production. The height of the mechanical barrier is adjustable during the process. Withdrawal crucibles for round ingots of $0.8 \mathrm{~m}$ diameter or slabs of e.g. $1.35 \mathrm{~m} \times 0.25 \mathrm{~m}$ can be installed to cast ingots up to a length of $3.5 \mathrm{~m}$.

Smaller EB systems with melting power of $200-300 \mathrm{~kW}$ are equipped with a cold hearth of approx. $150 \mathrm{~mm}$ width and $400 \mathrm{~mm}$ length. The water-cooled mechanical slag barrier separates the surface of the hearth into two areas. One of two installed EB guns melts the feedstock and heats the rear part of the trough. The second gun heats the hearth in front of the barrier, the overflow lip and the pool in the withdrawal crucible for ingots of up to $250 \mathrm{~mm}$ diameter.

\subsection{Button Melting}

Button melting processes are used to analyze the quality of steel or superalloy cast parts especially in regard to the content of low density inclusions (LDIs). ${ }^{4)}$ A sample of the material is drip melted in a process following predefined steps with controlled EB power distribution so as not to destroy the nonmetallic inclusions (Fig. 10). During the directional solidification process the nonmetallic inclusions are concentrated in the centre of the button for further metallographic investigations. However, the raft gives the first information about the quantity of impurities in the sample.

\section{Future Directions}

Industrial demands for highly clean materials and a reliable production system are still increasing: one example is the aircraft industry request for alloy cleanliness improvement and crack growth resistant materials ${ }^{15)}$ to be applied in engine disks. Production economics must also be improved: by using lower grade feeding material with reduced pretreatment input, the casting of near-end shape products like thin slabs or hollow ingots, the recycling of condensates occurring during the melt process and the increased use of computers to control the process based on data-feedback by continuous in situ analysis of the molten material.

These increasing demands for material produced under extremely clean and reproducible conditions, and the development and application of new materials like ceramic-free powders of reactive metals and alloys having intermetallic phases $(\mathrm{Ti}-\mathrm{Al}, \mathrm{Ni}-\mathrm{Ti}, \mathrm{Ti}-\mathrm{Si})$ will continue to drive progress in the electron beam melting technology. An outlook on these applications is shown in Fig. 11, whereby electron beam melting will replace or supplement existing methods.

\section{REFERENCES}

1) W. Dietrich and H. Stephan: Electron Beam Melting and Casting, Metals Handbook, Vol. 15, Casting, ASM Int., Ohio, (1988), 419.

2) H. Ranke, V. Bauer, W. Dietrich, J. Heimerl and H. Stephan: Melting and Evaporation with the Newly Developed LeyboldHeraeus $600 \mathrm{~kW}$ EB Gun at Different Pressure Levels, Proc. Conf. Electron Beam Melting and Refining, Reno, ed. by R. Bakish, (1985), 286.

3) H. Stephan: Production of Ingots and Cast Parts from Reactive Metals by Electron Beam Melting and Casting, Proc. 3rd EB Process. Seminar, Stratford, (1974), 150.

4) C. E. Shamblen, S. L. Culp and R. W. Lober: Superalloy Cleanliness Evaluation Using the EB Button Melt Test, Proc. Conf. Electron Beam Melting and Refining, Reno, (1983), 61.

5) F. Hauner, H. Stephan and H. Stumpp: Metall., 2 (1986), No. $40,2$.

6) C. d'A. Hunt and H. R. Smith: J. Met., 18 (1966), 570.

7) H. Stephan: Metall., (1975), 704.

8) C. d'A. Hunt, J. C. Lowe and T. H. Harrington: Electron Beam, Cold Hearth Refining for the Production of Nickel and Cobalt Base Superalloys. Proc. Conf. Electron Beam Melting and Refining, Reno, ed. by R. Bakish, (1983), 295.

9) H. R. Harker: The Present Status of Electron Beam Melting Technology, Proc. Conf. Electron Beam Melting and Refining, Reno, ed. by R. Bakish, (1986), 3.

10) H. Pannen, G. Sick and D. M. Wainhouse: High Power Plasma Melting of Titanium, Proc. Sixth World Conference on Titanium, (1988), 597. 
11) R. G. Reddy: Kinetics of TiN Dissolution in Ti Alloys, Proc. Conf. Electron Beam Melting and Refining, Reno, ed. by $\mathrm{R}$. Bakish, (1990), 119.

12) J. K. Tien and E. A. Schwarzkopf: Assessing the Needs for EB Refining of Superalloys, Proc. Conf. Electron Beam Melting and Refining, Reno, ed. by R. Bakish, (1983), 6.

13) F. Shimizu, T. Denda, N. Mori and K. Numa: Proc. Conf. Electron Beam Melting and Refining, Reno, ed. by R. Bakish, (1989), 134.
14) M. Krehl and I. C. Lowe: Electron Beam Cold Hearth Refining for Superalloy Revert for Use in Foundry Production, Proc. Conf. Electron Beam Melting and Refining, Reno, ed. by R. Bakish, (1986), 286.

15) C. E. Shamblen: Ongoing Challenges for Titanium Alley Cleanliness Improvement in Aircraft Engine Disk Materials, Proc. Conf. Electron Beam Melting and Refining, Reno, ed. by R. Bakish, (1990), 49. 